\title{
Magnetic resonance arthrography for femoroacetabular impingement surgery: is it reliable?
}

\author{
Alessandro Aprato $\cdot$ Alessandro Massè $\cdot$ \\ Carlo Faletti · Angiola Valente $\cdot$ Francesco Atzori \\ Maurizio Stratta $\cdot$ Narlaka Jayasekera
}

Received: 1 November 2011 / Accepted: 12 January 2013/Published online: 9 February 2013

(C) The Author(s) 2013. This article is published with open access at Springerlink.com

\begin{abstract}
Background Magnetic resonance arthrography (MRA) is commonly used to demonstrate injury to the labrum and hyaline cartilage in patients with femoroacetabular impingement (FAI). The purpose of this study was to assess the diagnostic correlation between MRA and findings at arthroscopic and open surgery.

Materials and methods MRA reports of 41 hips with symptomatic FAI were reviewed and compared with subsequent intraoperative findings $(n=21$ surgical dislocations and $n=20$ therapeutic hip arthroscopies). Each case was assessed for the presence of a cam deformity, a cartilage lesion of the femoral head, an os acetabuli, an injury to the labrum and injury to the acetabular cartilage. Results were collected prospectively in a cross-table and analysed retrospectively for sensitivity, specificity, positive predictive value (PPV) and negative predictive value (NPV).

Results The sensitivity, specificity, PPV and NPV in the presence of reported cam-type deformity or an os acetabuli were $100 \%$. In the presence of cartilage lesions of the femoral head, the values were $46,81,55$ and $73 \%$, respectively. For labral tears, the values were 91, 86, 97
\end{abstract}

\footnotetext{
A. Aprato $(\varangle) \cdot$ A. Massè · A. Valente $\cdot$ F. Atzori Pelvic Unit, Orthopaedic Department, II Faculty of Medicine, San Luigi Hospital of Orbassano, University of Turin, Regione Gonzole n.10, 10043 Turin, Orbassano, Italy e-mail: ale_aprato@hotmail.com

C. Faletti · M. Stratta

Department of Radiology, CTO Hospital of Turin, Turin, Italy

N. Jayasekera

The Richard Villar Practice, Spire Cambridge Lea Hospital, Cambridge, UK
}

and $67 \%$. In the presence of acetabular cartilage injuries, the values were $69,88,78$ and $81 \%$, respectively.

Conclusions MRA appears to be an efficacious imaging modality in the evaluation of labral tears, cam-type impingement lesions and os acetabuli of the hip. MRA is less efficacious in the diagnosis of cartilage abnormalities in the hip, both femoral and acetabular. Researchers should focus on further improvements in imaging techniques in order to give reliable preoperative information to the surgeon.

Keywords Femoroacetabular impingement . ArthroMRI · Hip

\section{Introduction}

Femoroacetabular impingement (FAI) is a recognised cause of hip pain in young adults and a precursor to osteoarthritis [1]. Abnormal femoral and acetabular morphology and lesions of the acetabular labrum and cartilage are common features in FAI. Surgical treatments for FAI include arthroscopy, mini invasive surgery and surgical dislocation [2]. Although there is no consensus on the correct indication for each treatment, surgical treatment should be directed by a precise preoperative diagnosis. Preoperative magnetic resonance arthrography of the hip [3] is useful in guiding surgery for an injured labrum and hyaline cartilage. Introduction of fluid into the hip joint causes the joint to distend and allows for better separation of intra-articular structures, thus allowing for better delamination of pathology at magnetic resonance imaging (MRI). Gadolinium enhancement further improves delamination of pathology involving the hip joint due to its ability to take advantage of the T1-shortening effect and 
extension of the dynamic range of contrast seen at MR imaging. Furthermore, the use of radial imaging has been described in the literature as a way to better visualise the acetabular labrum [4].

Although most surgeons agree that MRA plays a crucial role in guiding the best treatment for FAI, to our knowledge only a few studies have compared intraoperative findings with the findings of preoperative MRA. The purpose of this study was to assess the diagnostic accuracy of MRA reporting in the detection of these lesions.

\section{Materials and methods}

At our institution from 2008 to March 2010, all patients with a clinical diagnosis of FAI (inclusion criterion: a positive impingement test, defined as pain and decreased range of motion with flexion, adduction, and internal rotation of the hip) were evaluated with plain anteroposterior pelvic and lateral radiographs of the hip preoperatively. Patients with radiographic signs of osteoarthritis were excluded (Tonnis [5] grade $>1$ ). Informed consent was obtained from all patients enrolled onto this study. The study was performed in accordance with the ethical standards of the 1964 Declaration of Helsinki, as revised in 2000 and was approved by the Institutional Review Board.

Based on radiographic imaging [6], patients were attributed surgeons for the different types of FAI according to the following criteria:

1. Cam: alpha angle (as described by Tannast [6]) was $>50^{\circ}$, and no other sign of FAI was present.

2. Local pincer: an os acetabuli or a prominent anterior wall was present (positive crossover sign with a negative posterior wall sign) and the alpha angle was $<50^{\circ}$.

3. Pincer: there were signs of global acetabular deformity (positive crossover and posterior wall signs) or coxa profunda and an alpha angle of $<50^{\circ}$ were present.

4. Mixed: a local or global deformity was associated with a cam.

All enrolled patients were evaluated with MRA after obtaining their consent. All participants were informed of the risks, limitations, complications and benefits of the procedure. Under fluoroscopic guidance, into the superolateral portion of the coxofemoral joint, at the point of passage between the femoral head and neck, 2-3 $\mathrm{ml}$ of Iopamidol (Iopamiro $300^{\circledR}$, Bracco, Milan, Italy) were introduced through a spinal needle as radiopaque marker to locate the joint capsule.

The paramagnetic contrast agent was then introduced: the acid salt gadopentetic dimeglumine $\left(\right.$ Magnevist ${ }^{\circledR}$; BayerSchering, Leverkusen, Germany), at a concentration of $0.002 \mathrm{mmol} / \mathrm{ml}(2 \mathrm{mmol} / \mathrm{l})$, leading to a dose of $0.2 \mathrm{ml} / \mathrm{kg}$ of patient body weight. The MR procedure was started immediately after intra-articular administration of the paramagnetic contrast agent. We used $1.5 \mathrm{~T}$ equipment at our Department of Diagnostic Imaging (Excite, GE Medical Systems, Milwaukee, WI, USA). We applied traction of $5 \mathrm{~kg}$ to the ipsilateral ankle compared to the articulation coxofemoral joint in order to obtain a paraphysiological diastase of the articular heads and to improve the spread of the intra-articular contrast agent. Using a "TORSOPA" or "body" coil, the study protocol provided axial proton-density weighted images with saturation of the signal for adipose tissue (TR 1,300 ms, TE $51 \mathrm{~ms}$, FOV of $22 \mathrm{~cm}$, matrix of $416 \times 288$, slice thickness of $4 \mathrm{~mm}$, scan time $3^{\prime} 39^{\prime \prime}$ ), a T1-weighted scan in the coronal plane (TR $140 \mathrm{~ms}$, TE $3.6 \mathrm{~ms}$, FOV of $22 \mathrm{~cm}$, matrix of $416 \times 320$, slice thickness of $3 \mathrm{~mm}$, scan time $4^{\prime} 31^{\prime \prime}$ ), sagittal proton density weighted images with saturation of the signal for adipose tissue (TR 1,300 ms, TE $52 \mathrm{~ms}$, FOV of $24 \mathrm{~cm}$, matrix of $256 \times 224$, slice thickness of $4 \mathrm{~mm}$, scan time $4^{\prime} 10^{\prime \prime}$ ), and a radial proton density weighted FSPGR with saturation of the signal for the adipose tissue (TR 2,080 ms, TE $51.16 \mathrm{~ms}$, FOV of $20 \mathrm{~cm}$, matrix of $256 \times 320$, slice thickness of $3 \mathrm{~mm}$, scan time $\left.4^{\prime} 06^{\prime \prime}\right)$. In addition to the standard MRI protocol, radial PDW sequences (TR 2,000 ms, TE $15 \mathrm{~ms}$, FOV of $260 \times$ $260 \mathrm{~mm}$, matrix of $266 \times 512$, section thickness of $4 \mathrm{~mm}$, 16 slices, scan time $4^{\prime} 43^{\prime \prime}$ ) were oriented along the axis of the femoral neck. Magnetic resonance arthrography studies from external institutions were not included in the analysis because, in general, they showed poor spatial resolution, as they had been performed with a large field of view or with low-field-strength magnets.

The presence/absence of a cam-type deformity, a cartilage lesion of the femoral head, an os acetabuli, an injured labrum or an acetabular cartilage lesion was evaluated and recorded. A cam-type deformity was considered to be present when the alpha angle [6] was $>50^{\circ}$ at MRA. Cartilage delamination was considered to be present when hypointense areas in the acetabular cartilage seen on intermediate-weighted fat-saturated or T1-weighted images were present, or when the following two criteria were met: (1) at least two consecutive slices in the same plane or in the same location in two different planes showed focal discontinuity of cartilage and fluid located between the articular cartilage and subchondral bone plate, and (2) the area of abnormal cartilage was not completely detached from the adjacent cartilage [7]. Labral tears were considered positive if staged worse than grade IIA according to the Czerny classification [8]. Os acetabuli was defined as the presence of heterotopic bone on the acetabular rim.

All of the X-ray images and the MRA of these hips were analysed by two subspecialty-trained musculoskeletal 
radiologists, each with more than 5 years of experience in MRA of the hip joint. The analysis was performed jointly and before surgery.

Based on the clinical and radiological findings, patients were treated with either surgical dislocation (group A) or arthroscopy (group B) according to these criteria: arthroscopy was used in cases of cam-type deformity, focal anterior pincer, or mixed-type FAI (where the cam-type deformity was associated with a focal anterior pincer), while surgical dislocation was performed in cases of pincer or mixed type (where the cam deformity was associated with a coxa profunda or a pincer which, according to our experience, and as alluded to in the literature [2], can be difficult to treat arthroscopically).

The presence/absence of a cam-type deformity was detected intraoperatively in group A using a template, while a dynamic intraoperative assessment for impingement was utilised in group B. Cartilage lesions were assessed intraoperatively and considered positive in both groups if staged greater than grade 2 according to the Outerbridge classification and/or any signs of delamination were detected [9]. Injuries to the labrum were assessed intraoperatively by probing the labrum during arthroscopy and open surgery.
All (positive and negative) intraoperative findings were recorded (Figs. 1, 2).

Magnetic resonance arthrography reports were compared with intraoperative findings for both groups. For each group and for every item, results were collected in a crosstable and the sensitivity, specificity, positive predictive value (PPV), negative predictive value (NPV) and accuracy were calculated.

\section{Statistical analysis}

All patient data were recorded in a custom-made database and analysed using a commercial software package (TexaSoft, WINKS SDA software, 6th edn., Cedar Hill, TX, USA, 2007). Intraoperative findings at surgery and MRA findings in both groups were analysed with Pearson's chi-squared test of association. Statistical significance was fixed at $p<0.05$ for all tests performed.

\section{Results}

Forty-one patients met the inclusion criteria $(n=21$ in group A, $n=20$ in group B) (Table 1).
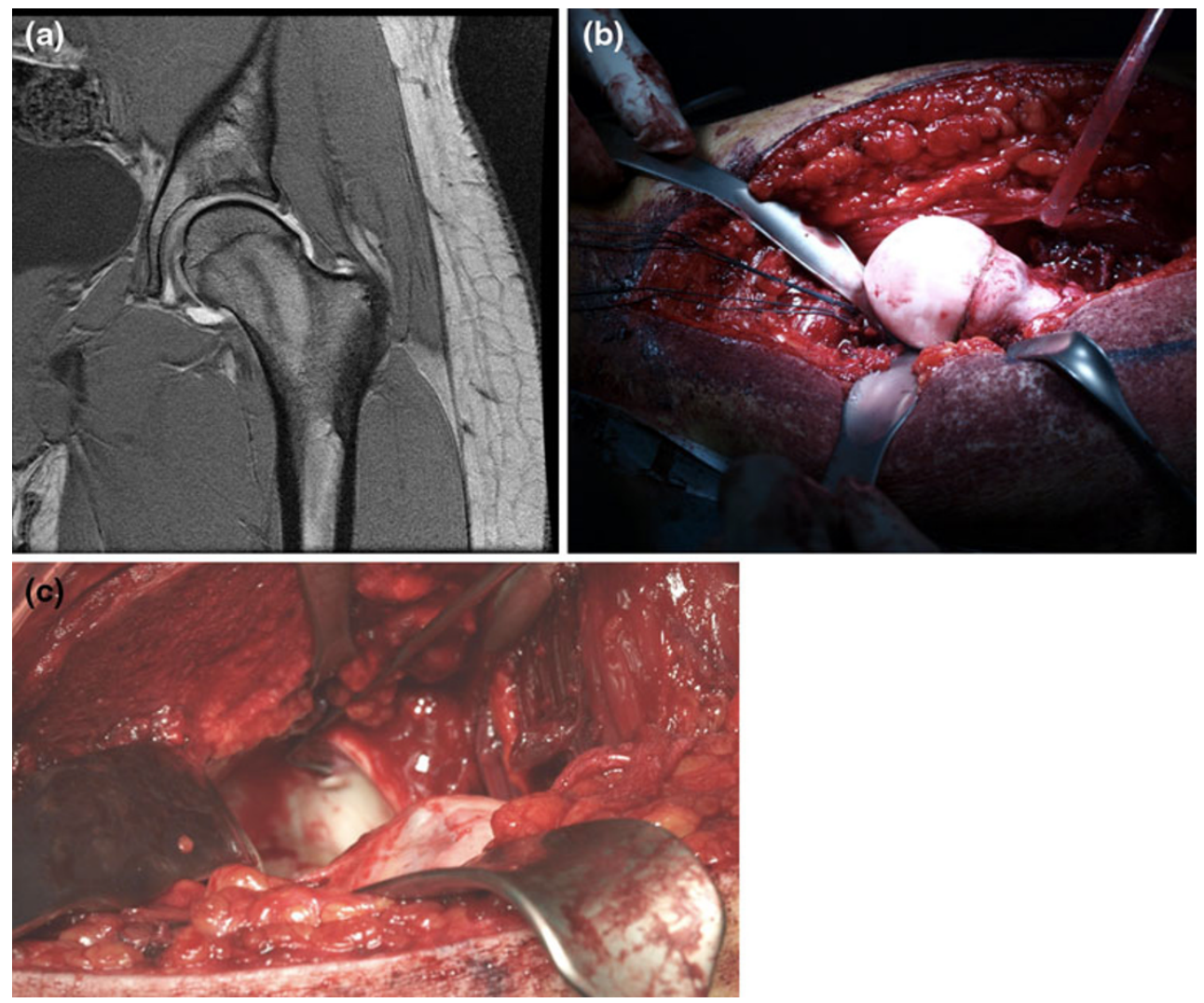

Fig. 1 MR arthrogram (a) shows a cam without an evident cartilage lesion; intraoperative pictures (b and c) show a cam with an acetabular cartilage lesion detected through hip dislocation 


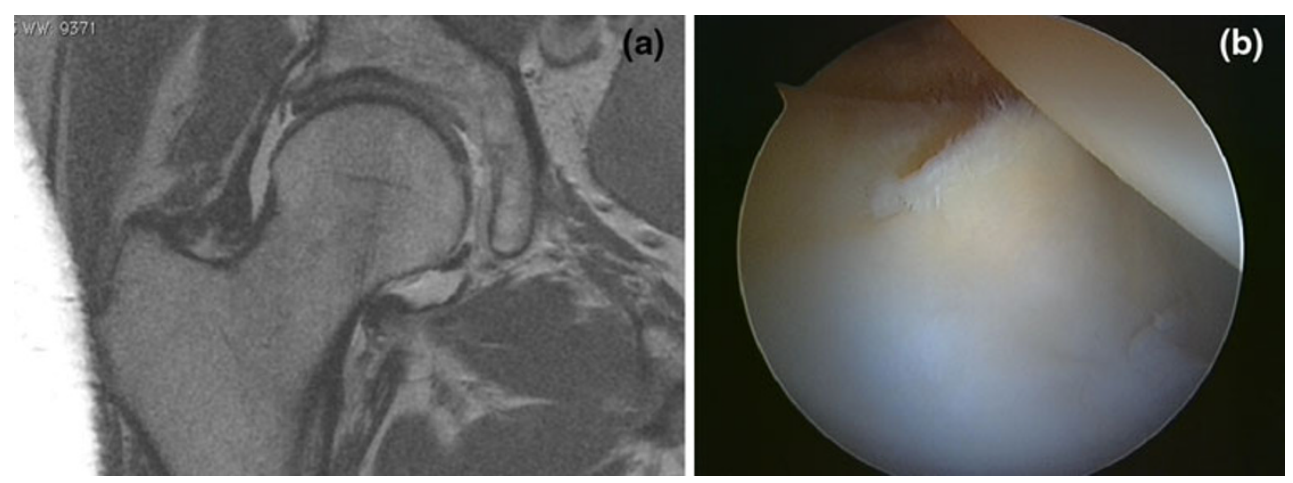

Fig. 2 MR arthrogram (a) shows a labral tear associated with an acetabular cartilage lesion; intraoperative arthroscopic images (b) confirm the report

Group A included 9 females and 12 males with an average age of 23 , while group B included 8 females and 12 males with an average age of 25 years.

The time interval between MRA and surgery was less than six months for all patients (range 2-6 months).

Examining the reports of cam deformities, overall sensitivity, specificity, PPV and NPV were found to be $100 \%$. For lesions of the femoral head cartilage, the sensitivity was $46 \%$, specificity was $81 \%$, PPV $55 \%$ and NPV $73 \%$. For os acetabuli, the sensitivity, specificity, PPV and NPV were all $100 \%$. For labral tears, the sensitivity was $91 \%$, specificity was $86 \%$, PPV was $97 \%$ and NPV was $67 \%$. For acetabular cartilage injuries, the sensitivity was $69 \%$, specificity $88 \%$, PPV $78 \%$ and NPV was $81 \%$ (Table 2).

\section{Discussion}

MRA is a recognized imaging modality for the detection of lesions of the acetabular labrum. In a recent meta-analysis [10] of 16 studies assessing the sensitivity and specificity of MRA, MRA demonstrated a sensitivity of $87 \%$ and specificity of $64 \%$. In our study, we achieved similar results, with an overall sensitivity of $91 \%$ and a specificity of $86 \%$. The diagnosis of cartilage delamination in the hip using MR arthrography has proven to be a challenge. The cartilage surfaces of the hip joint are often poorly delineated without arthrography, even when joint effusion is present.

Because of limited joint distensibility, cartilage delamination in the hip is difficult to detect, even with MRA. Mintz et al. [11] reported that non-enhanced MRI showed high accuracy in the evaluation of hip cartilage injuries (with 86-92\% agreement with arthroscopy in terms of the grade of cartilage injury). However, their study demonstrated no cases of cartilage delamination on either MRI or arthroscopy, a radically different finding from ours,
Anderson's [7] (in which the rate was $44 \%$ ), and Beck's study [12] (in which the rate was $38.5 \%$ ). Either these were different patient populations or Mintz et al. [11] simply failed to detect cartilage delaminations. Zlatkin et al. [13] detected 9 of 11 lesions (82\%) on MRI as well as indirect MRA, and stated that "conventional MRI evaluation was qualitatively equal to or better than indirect MRA in this evaluation". Furthermore, Pfirrmann et al. [3] evaluated 44 patients with a cam FAI and observed a sensitivity, specificity, and accuracy of $22-30,95$, and $57-61 \%$, respectively. Our study confirms poor sensitivity and specificity for cartilage lesions of the femoral head and the acetabulum, suggesting that, at present, MRA possesses only moderate accuracy for detecting cartilage lesions. In particular, partial thickness cartilage lesions, fissures, and nondisplaced flaps can be difficult to identify.

As the presence of cartilage delamination in the hip is correlated with a poorer surgical outcome, we are of the opinion that improvements in radiographic techniques are required so that more precise information can be provided to the surgeon prior to surgery. We feel that researchers should focus on improving MR procedures, such as the dGEMRIC technique (indirect assessment of articular cartilage glycosaminoglycan content by intravenous administration of gadolinium) [14], in order to give reliable preoperative information to the surgeon.

Our study has some limitations. We did not include a control group of healthy subjects, and the sample size was small, which does not permit statistical analysis. Furthermore, since this was a retrospective study, many patients with asymptomatic femoroacetabular impingement were likely not included in the data analysis. This is unavoidable, however: since the patients were selected on the basis of the presence of clinical signs of impingement, our study is likely to have included only patients with established disease. Although the alpha angle was used to quantify the abnormal head-neck junction, other methods of assessing the head-neck junction have been described previously. 
Table 1 Intraoperative and arthro-MRI findings for each patient

\begin{tabular}{|c|c|c|c|c|c|c|c|}
\hline Patient & $\begin{array}{l}\text { X-ray-based FAI } \\
\text { classification }\end{array}$ & Treatment & $\begin{array}{l}\text { Cam } \\
\text { MRI/intraop }\end{array}$ & $\begin{array}{l}\text { Femoral head } \\
\text { chondral lesion } \\
\text { MRI/intraop }\end{array}$ & $\begin{array}{l}\text { Os acetabuli } \\
\text { MRI/intraop }\end{array}$ & $\begin{array}{l}\text { Labral lesion } \\
\text { RMN/intraop }\end{array}$ & $\begin{array}{l}\text { Acetabular } \\
\text { chondral lesion } \\
\text { RMN/intraop }\end{array}$ \\
\hline 1 & Cam & Arthroscopy & $\mathrm{y} / \mathrm{y}$ & $\mathrm{y} / \mathrm{y}$ & $\mathrm{n} / \mathrm{n}$ & $\mathrm{n} / \mathrm{n}$ & $\mathrm{n} / \mathrm{n}$ \\
\hline 2 & Cam & Arthroscopy & $\mathrm{y} / \mathrm{y}$ & $\mathrm{n} / \mathrm{y}$ & $\mathrm{n} / \mathrm{n}$ & $\mathrm{n} / \mathrm{y}$ & $y / n$ \\
\hline 3 & Cam & Arthroscopy & $\mathrm{y} / \mathrm{y}$ & $\mathrm{n} / \mathrm{n}$ & $\mathrm{n} / \mathrm{n}$ & $\mathrm{n} / \mathrm{y}$ & $\mathrm{y} / \mathrm{y}$ \\
\hline 4 & Cam & Arthroscopy & $\mathrm{y} / \mathrm{y}$ & $\mathrm{n} / \mathrm{n}$ & $\mathrm{n} / \mathrm{n}$ & $\mathrm{y} / \mathrm{y}$ & $\mathrm{n} / \mathrm{n}$ \\
\hline 5 & Local pincer & Arthroscopy & $\mathrm{n} / \mathrm{n}$ & $\mathrm{n} / \mathrm{y}$ & $\mathrm{y} / \mathrm{y}$ & $\mathrm{n} / \mathrm{y}$ & $\mathrm{n} / \mathrm{n}$ \\
\hline 6 & Cam & Arthroscopy & $\mathrm{y} / \mathrm{y}$ & $y / n$ & $\mathrm{n} / \mathrm{n}$ & $\mathrm{n} / \mathrm{n}$ & $y / n$ \\
\hline 7 & Mixed & Arthroscopy & $\mathrm{y} / \mathrm{y}$ & $\mathrm{n} / \mathrm{n}$ & $\mathrm{n} / \mathrm{n}$ & $\mathrm{y} / \mathrm{y}$ & $\mathrm{n} / \mathrm{n}$ \\
\hline 8 & Mixed & Arthroscopy & $\mathrm{y} / \mathrm{y}$ & $\mathrm{n} / \mathrm{n}$ & $\mathrm{n} / \mathrm{n}$ & $\mathrm{y} / \mathrm{y}$ & $\mathrm{y} / \mathrm{y}$ \\
\hline 9 & Mixed & arthroscopy & $\mathrm{y} / \mathrm{y}$ & $\mathrm{n} / \mathrm{y}$ & $\mathrm{n} / \mathrm{n}$ & $\mathrm{y} / \mathrm{y}$ & $\mathrm{n} / \mathrm{y}$ \\
\hline 10 & Local pincer & Arthroscopy & $\mathrm{n} / \mathrm{n}$ & $\mathrm{n} / \mathrm{n}$ & $\mathrm{y} / \mathrm{y}$ & $\mathrm{y} / \mathrm{n}$ & $\mathrm{n} / \mathrm{n}$ \\
\hline 11 & Cam & Arthroscopy & $\mathrm{n} / \mathrm{n}$ & $\mathrm{y} / \mathrm{y}$ & $\mathrm{n} / \mathrm{n}$ & $\mathrm{y} / \mathrm{y}$ & $\mathrm{n} / \mathrm{n}$ \\
\hline 12 & Cam & Arthroscopy & $\mathrm{y} / \mathrm{y}$ & $y / n$ & $\mathrm{n} / \mathrm{n}$ & $\mathrm{y} / \mathrm{y}$ & $\mathrm{n} / \mathrm{n}$ \\
\hline 13 & Cam & Arthroscopy & $\mathrm{y} / \mathrm{y}$ & $\mathrm{n} / \mathrm{y}$ & $\mathrm{n} / \mathrm{n}$ & $\mathrm{y} / \mathrm{y}$ & $\mathrm{n} / \mathrm{n}$ \\
\hline 14 & Cam & Arthroscopy & $\mathrm{y} / \mathrm{y}$ & $\mathrm{n} / \mathrm{n}$ & $\mathrm{n} / \mathrm{n}$ & $\mathrm{y} / \mathrm{y}$ & $\mathrm{n} / \mathrm{n}$ \\
\hline 15 & Mixed & Arthroscopy & $y / y$ & $\mathrm{n} / \mathrm{y}$ & $\mathrm{n} / \mathrm{n}$ & $\mathrm{y} / \mathrm{y}$ & $\mathrm{n} / \mathrm{n}$ \\
\hline 16 & Cam & Arthroscopy & $y / y$ & $y / y$ & $\mathrm{n} / \mathrm{n}$ & $\mathrm{n} / \mathrm{n}$ & $\mathrm{n} / \mathrm{n}$ \\
\hline 17 & Cam & Arthroscopy & $y / y$ & $\mathrm{n} / \mathrm{n}$ & $\mathrm{n} / \mathrm{n}$ & $\mathrm{y} / \mathrm{y}$ & $\mathrm{n} / \mathrm{n}$ \\
\hline 18 & Mixed & Arthroscopy & $y / y$ & $y / y$ & $\mathrm{n} / \mathrm{n}$ & $\mathrm{y} / \mathrm{y}$ & $\mathrm{y} / \mathrm{y}$ \\
\hline 19 & Cam & Arthroscopy & $\mathrm{y} / \mathrm{y}$ & $y / n$ & $\mathrm{n} / \mathrm{n}$ & $\mathrm{y} / \mathrm{y}$ & $\mathrm{n} / \mathrm{n}$ \\
\hline 20 & Local pincer & Arthroscopy & $\mathrm{n} / \mathrm{n}$ & $\mathrm{n} / \mathrm{n}$ & $\mathrm{y} / \mathrm{y}$ & $\mathrm{y} / \mathrm{y}$ & $\mathrm{n} / \mathrm{n}$ \\
\hline 21 & Mixed & Dislocation & $\mathrm{y} / \mathrm{y}$ & $\mathrm{n} / \mathrm{n}$ & $\mathrm{n} / \mathrm{n}$ & $\mathrm{n} / \mathrm{n}$ & $y / y$ \\
\hline 22 & Mixed & Dislocation & $y / y$ & $\mathrm{n} / \mathrm{n}$ & $\mathrm{n} / \mathrm{n}$ & $\mathrm{y} / \mathrm{y}$ & $\mathrm{n} / \mathrm{y}$ \\
\hline 23 & Mixed & Dislocation & $\mathrm{y} / \mathrm{y}$ & $\mathrm{n} / \mathrm{y}$ & $y / y$ & $\mathrm{y} / \mathrm{y}$ & $\mathrm{n} / \mathrm{n}$ \\
\hline 24 & Mixed & Dislocation & $y / y$ & $\mathrm{n} / \mathrm{y}$ & $y / y$ & $y / y$ & $\mathrm{n} / \mathrm{n}$ \\
\hline 25 & Pincer & Dislocation & $\mathrm{n} / \mathrm{n}$ & $\mathrm{n} / \mathrm{n}$ & $\mathrm{n} / \mathrm{n}$ & $\mathrm{y} / \mathrm{y}$ & $\mathrm{n} / \mathrm{n}$ \\
\hline 26 & Pincer & Dislocation & $\mathrm{n} / \mathrm{n}$ & $y / n$ & $\mathrm{n} / \mathrm{n}$ & $\mathrm{n} / \mathrm{n}$ & $y / y$ \\
\hline 27 & Mixed & Dislocation & $\mathrm{y} / \mathrm{y}$ & $\mathrm{n} / \mathrm{n}$ & $\mathrm{n} / \mathrm{n}$ & $\mathrm{y} / \mathrm{y}$ & $\mathrm{n} / \mathrm{y}$ \\
\hline 28 & Mixed & Dislocation & $\mathrm{y} / \mathrm{y}$ & $\mathrm{y} / \mathrm{y}$ & $\mathrm{n} / \mathrm{n}$ & $\mathrm{y} / \mathrm{y}$ & $y / y$ \\
\hline 29 & Mixed & Dislocation & $\mathrm{y} / \mathrm{y}$ & $\mathrm{n} / \mathrm{n}$ & $\mathrm{n} / \mathrm{n}$ & $\mathrm{y} / \mathrm{y}$ & $y / y$ \\
\hline 30 & Mixed & Dislocation & $\mathrm{y} / \mathrm{y}$ & $\mathrm{n} / \mathrm{n}$ & $y / y$ & $\mathrm{y} / \mathrm{y}$ & $\mathrm{n} / \mathrm{n}$ \\
\hline 31 & Mixed & Dislocation & $\mathrm{y} / \mathrm{y}$ & $\mathrm{y} / \mathrm{y}$ & $\mathrm{n} / \mathrm{n}$ & $\mathrm{y} / \mathrm{y}$ & $\mathrm{y} / \mathrm{y}$ \\
\hline 32 & Mixed & Dislocation & $\mathrm{y} / \mathrm{y}$ & $\mathrm{n} / \mathrm{n}$ & $\mathrm{n} / \mathrm{n}$ & $\mathrm{y} / \mathrm{y}$ & $\mathrm{y} / \mathrm{y}$ \\
\hline 33 & Mixed & Dislocation & $\mathrm{y} / \mathrm{y}$ & $\mathrm{n} / \mathrm{n}$ & $\mathrm{n} / \mathrm{n}$ & $\mathrm{y} / \mathrm{y}$ & $\mathrm{n} / \mathrm{y}$ \\
\hline 34 & Mixed & Dislocation & $\mathrm{y} / \mathrm{y}$ & $\mathrm{n} / \mathrm{n}$ & $\mathrm{n} / \mathrm{n}$ & $\mathrm{y} / \mathrm{y}$ & $y / y$ \\
\hline 35 & Mixed & Dislocation & $\mathrm{y} / \mathrm{y}$ & $\mathrm{n} / \mathrm{n}$ & $\mathrm{n} / \mathrm{n}$ & $\mathrm{y} / \mathrm{y}$ & $\mathrm{n} / \mathrm{n}$ \\
\hline 36 & Pincer & Dislocation & $\mathrm{n} / \mathrm{n}$ & $\mathrm{n} / \mathrm{y}$ & $\mathrm{n} / \mathrm{n}$ & $\mathrm{y} / \mathrm{y}$ & $\mathrm{n} / \mathrm{n}$ \\
\hline 37 & Mixed & Dislocation & $\mathrm{y} / \mathrm{y}$ & $y / n$ & $\mathrm{n} / \mathrm{n}$ & $\mathrm{y} / \mathrm{y}$ & $\mathrm{n} / \mathrm{y}$ \\
\hline 38 & Mixed & Dislocation & $\mathrm{y} / \mathrm{y}$ & $\mathrm{n} / \mathrm{n}$ & $\mathrm{n} / \mathrm{n}$ & $\mathrm{y} / \mathrm{y}$ & $\mathrm{n} / \mathrm{n}$ \\
\hline 39 & Mixed & Dislocation & $\mathrm{y} / \mathrm{y}$ & $\mathrm{n} / \mathrm{n}$ & $\mathrm{y} / \mathrm{y}$ & $\mathrm{y} / \mathrm{y}$ & $\mathrm{y} / \mathrm{y}$ \\
\hline 40 & Mixed & Dislocation & $\mathrm{y} / \mathrm{y}$ & $\mathrm{n} / \mathrm{n}$ & $\mathrm{n} / \mathrm{n}$ & $\mathrm{n} / \mathrm{n}$ & $y / n$ \\
\hline 41 & Mixed & Dislocation & $\mathrm{y} / \mathrm{y}$ & $\mathrm{n} / \mathrm{n}$ & $\mathrm{y} / \mathrm{y}$ & $\mathrm{y} / \mathrm{y}$ & $\mathrm{n} / \mathrm{n}$ \\
\hline
\end{tabular}

All seem to be acceptable quantitative methods. In our study, we used alpha-angle measurement because it was the most feasible method with regard to the use of existing tools on the clinical workstation.
MR arthrography provides reliable information about the presence of a cam-type deformity or an os acetabuli. Once again, this study confirms that MRA is an accurate imaging modality for the assessment of labral injury. 
Table 2 Sensitivity, specificity, PPV and NPV are shown for group $\mathrm{A}$ and $\mathrm{B}$ lesions

\begin{tabular}{|c|c|c|c|}
\hline & Dislocation & Arthroscopy & All \\
\hline \multicolumn{4}{|l|}{ Cam deformity } \\
\hline Sensitivity (\%) & 100 & 100 & 100 \\
\hline Specificity (\%) & 100 & 100 & 100 \\
\hline PPV (\%) & 100 & 100 & 100 \\
\hline NPV (\%) & 100 & 100 & 100 \\
\hline Accuracy (\%) & 100 & 100 & 100 \\
\hline$p$ value & $<0.001$ & $<0.001$ & $<0.001$ \\
\hline \multicolumn{4}{|c|}{ Femoral head cartilage injury } \\
\hline Sensitivity (\%) & 50 & 44 & 46 \\
\hline Specificity (\%) & 82 & 73 & 81 \\
\hline PPV (\%) & 40 & 57 & 55 \\
\hline NPV (\%) & 88 & 62 & 73 \\
\hline Accuracy (\%) & 76 & 60 & 68 \\
\hline$p$ value & 0.172 & 0.432 & 0.095 \\
\hline \multicolumn{4}{|l|}{ Os acetabuli } \\
\hline Sensitivity (\%) & 100 & 100 & 100 \\
\hline Specificity (\%) & 100 & 100 & 100 \\
\hline PPV (\%) & 100 & 100 & 100 \\
\hline NPV (\%) & 100 & 100 & 100 \\
\hline Accuracy (\%) & 100 & 100 & 100 \\
\hline$p$ value & $<0.001$ & $<0.001$ & $<0.001$ \\
\hline \multicolumn{4}{|l|}{ Labral tear } \\
\hline Sensitivity (\%) & 100 & 81 & 91 \\
\hline Specificity (\%) & 100 & 75 & 86 \\
\hline PPV (\%) & 100 & 93 & 97 \\
\hline NPV $(\%)$ & 100 & 50 & 67 \\
\hline Accuracy $(\%)$ & 100 & 80 & 93 \\
\hline$p$ value & $<0.001$ & 0.028 & $<0.001$ \\
\hline \multicolumn{4}{|c|}{ Acetabular cartilage injury } \\
\hline Sensitivity (\%) & 67 & 75 & 69 \\
\hline Specificity (\%) & 89 & 88 & 88 \\
\hline PPV (\%) & 89 & 60 & 78 \\
\hline NPV $(\%)$ & 67 & 93 & 81 \\
\hline Accuracy $(\%)$ & 76 & 85 & 80 \\
\hline$p$ value & 0.034 & 0.068 & 0.04 \\
\hline
\end{tabular}

At present, the role of MR arthrography in evaluating cartilage lesions appears to be limited.

\section{Conflict of interest None.}

Open Access This article is distributed under the terms of the Creative Commons Attribution License which permits any use, distribution, and reproduction in any medium, provided the original author(s) and the source are credited.

\section{References}

1. Ganz R, Parvizi J, Beck M, Leunig M, Notzli H, Siebenrock KA (2003) Femoroacetabular impingement: a cause for osteoarthritis of the hip. Clin Orthop Relat Res 417:112-120

2. Beaulè PE, Allen DJ, Clohisy JC, Schoenecker P, Leunig M (2009) The young adult with hip impingement: deciding on the optimal intervention. J Bone Jt Surg Am 91:210-221

3. Pfirrmann CW, Duc SR, Zanetti M, Dora C, Hodler J (2008) MR arthrography of acetabular cartilage delamination in femoroacetabular cam impingement. Radiology 249:236-241

4. Plötz GM, Brossmann J, von Knoch M, Muhle C, Heller M, Hassenpflug J (2001) Magnetic resonance arthrography of the acetabular labrum: value of radial reconstructions. Arch Orthop Trauma Surg 121:450-457

5. Tonnis D (1987) Congenital dysplasia and dislocation of the hip in children and adults. Springer, New York, pp 113-130

6. Tannast M, Siebenrock KA, Anderson SE (2007) Femoroacetabular impingement: radiographic diagnosis-what the radiologist should know. Am J Roentgenol 188:1540-1552

7. Anderson LA, Peters CL, Park BB, Stoddard GJ, Erickson JA, Crim JR (2009) Acetabular cartilage delamination in femoroacetabular impingement. Risk factors and magnetic resonance imaging diagnosis. J Bone Jt Surg Am 91:305-313

8. Czerny C, Hofmann S, Urban M et al (1999) MR arthrography of the adult acetabular capsular-labral complex: correlation with surgery and anatomy. Am J Roentgenol 173:345-349

9. Adler CP (2004) Bone diseases. Springer, Heidelberg, pp 430s-435s

10. Smith TO, Hilton G, Toms AP, Donell ST, Hing CB (2011) The diagnostic accuracy of acetabular labral tears using magnetic resonance imaging and magnetic resonance arthrography: a metaanalysis. Eur Radiol 21:863-874

11. Mintz DN, Hooper T, Connell D, Buly R, Padgett DE, Potter HG (2005) Magnetic resonance imaging of the hip: detection of labral and chondral abnormalities using noncontrast imaging. Arthroscopy 21:385-393

12. Beck M, Kalhor M, Leunig M, Ganz R (2005) Hip morphology influences the pattern of damage to the acetabular cartilage: femoroacetabular impingement as a cause of early osteoarthritis of the hip. J Bone Jt Surg Br 87:1012-1018

13. Zlatkin MB, Pevsner D, Sanders TG et al (2010) Acetabular labral tears and cartilage lesions of the hip: indirect MR arthrographic correlation with arthroscopy-a preliminary study. AJR Am J Roentgenol 194:709-714

14. Mamisch TC, Kain MS, Bittersohl B, Apprich S, Werlen S, Beck M, Siebenrock KA (2011) Delayed gadolinium-enhanced magnetic resonance imaging of cartilage (dGEMRIC) in femoacetabular impingement. J Orthop Res 29:1305-1311 